\title{
Migration, remittances and child education in Ghana. Evidence from a longitudinal study
}

\author{
Victor Cebotari ${ }^{1}$
}

This is an original manuscript of a book chapter published by Routledge

[DOI: $10.4324 / 9780429288814-8$ ]

\footnotetext{
${ }^{1}$ University of Luxembourg, Office of the Vice-rector for Academic Affairs, Maison du Savoir, 2, Avenue de l'Université, L-4365 Esch-sur-Alzette, Luxembourg; Maastricht Graduate School of Governance \& United Nations University - MERIT, Boschstraat 24, 6211 AX Maastricht, Netherlands: victor.cebotari@uni.lu, victor.cebotari@maastrichtuniversity.nl
} 


\begin{abstract}
Evidence on the time-varying effects of migration, remittances and child education in African contexts remains scarce. This study employs panel data to examine educational outcomes school enjoyment, and class ranking - of children whose parents migrated internally or internationally and who received in-kind remittances, monetary remittances, or both. The data were collected in 2013, 2014, and 2015 on a panel of school going children and youths aged from 12 to 21 in two urban areas with high out-migration rates in Ghana: Kumasi and Sunyani $(\mathrm{N}=741)$. The panel includes children of both migrant and non-migrant parents. Results indicate dynamic patterns of sending remittances over years, with preferences converging towards sending both in-kind and monetary remittances by internal and international migrant parents. Overall, the education of children benefits when they receive both in-kind and monetary remittances. The positive effects are further enhanced when remittances are directly invested in child education. The absence of remittances has more negative effects on child education, especially for girls. This study gives a more nuanced understanding of the dynamic and intertwined associations between parental migration, remittances and the education of children in transnational families.
\end{abstract}




\section{INTRODUCTION}

According to official statistics, there were 417 thousands international Ghanaian migrants in 2017 (United Nations. Department of Economic and Social Affairs. Population Division, 2017). Some sources, however, put the number of Ghanaians residing abroad at 1.5 million (Government of Ghana, 2016). Within the country, an estimated 8 million Ghanaians have migrated internally, from rural to urban areas in the past two decades (Molini \& Paci, 2015). These migrants contribute vital financial resources to their families and the country's economy. In Sub-Saharan Africa, Ghana is second only to Nigeria in the amount of remittances received from nationals working abroad. Specifically, in 2018, the inflow of Ghanaian remittances accounted to 3.8 billion US\$, up from 136 million US\$ in 2010. The remitting inflow of 2018 represents 7.4\% of Ghana's Gross Domestic Product (GDP) (World Bank, 2018). The size and scale of in-kind remittances are unknown, largely due to informality and the undeclared status of these flows.

Many Ghanaian migrants are parents who migrate internally or internationally to provide better opportunities for their children and other family members who often stay behind. Nationwide, about $37 \%$ of all Ghanaian children, excluding orphans, have at least one biological parent away, although the parent-child separation is not always due to migration (Ghana Statistical Service-Ghana Health Service and ICF International, 2014). Monetary and in-kind remittances sent back by migrant parents are used to pay for school fees, books and other educational necessities, thus creating an assumption that children are the net beneficiaries of migration (Bredl, 2010). Under these circumstances, a body of literature on parental migration, 
remittances, and educational outcomes of children is burgeoning (Acosta, 2011; Antman, 2012;

Cebotari, 2018; Cebotari \& Mazzucato, 2016; Cortes, 2015; Kroeger \& Anderson, 2014).

Through detailed case studies, these studies inform theoretical and empirical evidence on the educational outcomes of children when parents migrate and remit. The evidence shows that parental migration often results in income gains with subsequent benefits for children's education (Antman, 2012; Cebotari, 2018; Edwards \& Ureta, 2003; Kandel \& Kao, 2001). Children seem to benefit more when remittances are invested in better schools, educational material, and learning support (Rapoport \& Docquier, 2006). These invetments, however, may be constrained when parents send no or scarce remittances and when remittances are not invested in children's education (Cebotari, Siegel, \& Mazzucato, 2016; Cortes, 2015; Kroeger \& Anderson, 2014).

This study builds on existing gaps and intends to make novel contributions in several ways. First, the analysis adds a holistic perspective on migration by simultaneusely looking at both internal and international parental migration and the different types of remittances. The literature on parental migration and remittances has predominately looked at international remitting channels, with few studies looking at remittances from internal migration but not necessarily linked to child education (see for instance Ackah \& Medvedev, 2012; Molini, Pavelesku, \& Ranzani, 2016). We know from recent longitudinal findings in Ghana that parents frequently change their migration status, shifting between being an internal, international, or non-migrant over the years, and it is rather common for children to simultaneusely have one parent away internally while the other parent is away internationally (Cebotari, Mazzucato, \& Appiah, 2018). 
There is a gap in the literature on transnational families on how internal and international remittances associate with children's education.

Second, this study includes measurements of both monetary and in-kind remittances. The literature almost exclusevely looks at the effects of monetary flows in relation to children's education. Only a handful of studies have used evidence of non-monetary remittances when measuring child education (Cebotari, 2018; Cebotari et al., 2016; Kroeger \& Anderson, 2014). This gap in evidence hinders our understanding of whether the effects of remittances on education is entirely due to monetary investments in children.

Third, data used in this study employs child reports for measuring migration, remittances, and education outcomes. Existing studies rely almost exclusevely on adult reports to advance empirical and theoretical evidence on child wellbeing. Recent studies show that children assess and report their educational outcomes differently from adults (Cebotari et al., 2016; Jordan \& Graham, 2012).

Finally, this is the first study to employ longitudinal evidence to look at monetary and in-kind remittances and to assess their effects on child education in an African context. Transnational characterisitcs are dynamic events and for the most part, existing studies rely on snapshot data to advance the knowledge on children in transnational care (although see Cebotari et al., 2018; Gatskova, Ivlevs, \& Dietz, 2017; Jampaklay, 2006; Nobles, 2011).

This sudy includes a sample of children aged between 12 and 21 years. The age range reflects the distribution of children in classrooms in the surveyed schools. The term "children" is 
therefore used to reflect the relationship pupils have with migrant parents. In the following, I discuss the transnational dynamics and how they associate with child education.

\section{BACKGROUND}

\section{Migration, remittances and child education}

Time and money are two chanels through which parents invest resources in their children (Thomson, Hanson, \& McLanahan, 1994). Along these lines, there are benefits and risks for children when parents migrate. According to the household srategy theory, parental migration is a strategy to maximize the wellbeing of children and other family members who stay behind (Stark \& Bloom, 1985). Migrant parents enhance the economic welfare of their family by regularly sending remittances. The monetary and in-kind resources improve the soioeconomic status and wellbeing of children by facilitating investments and their upward social mobility. In Mexico, research shows that children in migrant households are economiclaly better than children in non-migrant household (Morooka \& Liang, 2009). Furthermore, evidence from China shows that children in migrant families with a better socioeconomic status have better educational outcomes (Wen \& Lin, 2012). In many countries, parental migration was found to boost educational expenditures, with positive effects on children's school attainment, performance, educational aspirations, and school enjoyment (Antman, 2012; Cebotari, 2018;

Cebotari \& Mazzucato, 2016; Edwards \& Ureta, 2003; Kandel \& Kao, 2001). It is likely that the effects of remittances on child education depend on the capacity and willingness of families to invest in children's schooling and to mitigate the household constraints that keep children away from school (Brown \& Poirine, 2005; Cebotari et al., 2016). 
The specific effects of monetary and in-kind remittances on child education are not always straightforward in the literature. Typiclaly, monetary remittances are received by children's caregivers, which use those resources to pay for school expences but also for a variety of household goods and services (Poeze, 2018). At the same time, in-kind remittances contribute to the commodification of love, in that gifts and material goods attempt to recreate the emotional intimacy and parental care from a distance (Coe, 2011; Parreñas, 2001). The flow of in-kind remittances may be an imperfect replacement of parental care but in practice, intimate connections and child education are deeply intertwined. Empirical studies show that children who have a good quality relationship with their migrant parents have better grades and enjoy school more (Cebotari \& Mazzucato, 2016; Cebotari et al., 2018; Jordan \& Graham, 2012). Similarly, children whose caregivers are happier are more likely to report an above average ranking in their class when living transnationally (Cebotari et al., 2016). However, the access to remittances can be a source of conflict between migrant parents and children's caregivers and may affect investments in children, including in education (Poeze, 2018).

Despite the evidence on the effects of remittances on child education, questions remain about whether parental migration, and its remitting potential, is indeed a successful strategy to improve the wellbeing of children (Adams \& Page, 2005). A consequence of parental migration is parental absence, which often has emotional costs for the children (Jordan \& Graham, 2012; Mazzucato \& Cebotari, 2016). According to the attachment theory (Bowlby, 1958), a child's meaningful development relates to the proximity, stability and long-term atatchment with a caregiver. Indeed, parental absence can be injurious to the education of a child due to a lessen parental support and guidance during school cycles. These effects are normally independent 
from the remitting potential of migrant parents. In Philippines, evidence shows that children in transnational care tend to lag behind in schools when controls for remittances are applied (Cortes, 2015).

For the most part, transnational family studies look at international migration. A large body of research has been conducted in the context of China and looks at internal migration, albeit over large distances (Hu, 2012; Wen \& Lin, 2012). To date, the effects of internal versus international migration on children's education have not been well examined. One of the few studies that looked at the effects of internal and international parental migration in Mexico and Indonesia found that international migration is more detrimental to children's school attendance than internal migration (Lu, 2014). In Ghana, Cebotari and Mazzucato (2016) found similar patters, in that the school performance of children whose parents migrated internationally is lower compared to children whose parents migrated internally. This evidence suggests that internal and international parental migration may have different effects on children. Internal parental migration implies a closer geographical proximity and less administrattive and financial difficulties for parents and children to regularly see each other on a regular basis. At the same time, international migration allows for a greater earning potential compared to internal migration, which may directly influence investments in children's education (Cebotari et al., 2016; Lu, 2014). However, international migration brings in higher expectations of reunificaion and material benefits among children, which may lead to feelings of abandonment and distress when these expectations are not met (Parreñas, 2005; Wu \& Cebotari, 2018). The difficult situation that many parents encount at destination may add to these difficulties and may affect children's wellbeing more negatively (Poeze, 2018). 
The evidence from the literature suggest that the relationship between parental migration and child education is also gendered. The dominant narrative is one in which girls are more disadvantaged, compared to boys, when investments are made in domains of wellbeing such as education. In Ghana, evidence shows that girls are more likely than boys to compensate for shortages in household labor, and they change residences more often when parents migrate (Whitehead, Hashim, \& Iversen, 2007). Furthermore, Ghanaian girls are more at risk to have poorer wellbeing outcomes, including education, when parents migrate internaly or internationally (Cebotari et al., 2018). In other contexts, studies found that parental migration does not necessarily affect the education of girls more negatively. For instance, in Mexico and El Salvador, parental migration associates positively with girls' school attainment (Acosta, 2011; Antman, 2012), while in Tajikistan it associates with girls' normal school progress (Cebotari, 2018).

In this study, the normative context of family functioning is also important to be considered. In Ghana, it is common for many children to live in the care of someone other than their biological parents. When parents migrate, leaving children behind in the care of a trusted family or nonfamily member is often a preffered choice. When living in foster care, Ghanaian children were found to accomodate well to the new families and they build harmonious reltionships with their caregivers (Poeze, 2018). Many schools in Ghana also feature a high-quality boarding service and migrant parents, at times, use these facilities for their children who stay behind (Bledsoe \& Sow, 2011).

Drawing on the above-mentioned literature, this study investigates different transnational family configurations that take into account the diversity of internal and international parental 
migration and their remitting patterns in relation to children education. This evidence and the longitudinal dimension of the analysis provides a more detailed insight into the measures being analysed and their time varying effects.

\section{METHOD}

\section{Data}

This study uses panel data collected in 2013, 2014, and 2015 among children and youths aged 12-21, in Kumasi and Sunyani, two urban areas with high out-migration rates in Ghana. A national data sampling strategy was not considered due to urban clustering of high outmigration patterns in the country.

Following a stratified sampling procedure, eight low- and high-quality public and private junior high schools (JHS) and senior high schools (SHS) were selected in the two urban locations. The Ministry of Education in Ghana provides annual rankings of public and private schools based on their enrollment rates and final exam performance. A random list generator was employed to select an equal number of JHS and SHS, public and private, and low- and high-quality schools in the two urban locations. Selected schools were approached and asked to participate, all of which agreed to take part in the survey. For the first round of the survey, one class from each of the first two grades was randomly selected in each school. In these classes, all children were asked to fill in the questionnaires. In remaining classess of the first two grades, a purposive sampling was applied to select a sufficient number of children with internal and international migrant parents. Children of migrants were purposevely oversampled to allow for a sufficient number of children in transnational care to fulfill the study's objective of comparing children 
with a migrant and non-migrant background. All these children were subsequently followed in the next rounds of the survey, ensuring that they have at least two years of participation in the panel.

During data collection, children were informed of the study's purpose and of the volunary nature of their participation. The questionnaire was administered in English and filled in by students themselves under the guidance of the surveying team. The same team composed of five trained data collection specialists collected the three rounds of data. In JHS, the survival rates of panel children were $83 \%$ in the second round and $96 \%$ in the third round. Similarly, the survival rates of SHS panel children were $82 \%$ and $85 \%$ in rounds two and three, respectively. Main reasons for panel attrition were school dropout and children changing schools.

In total, 985 unique respondents were sampled at the start of the survey, of which 405 filled in the questionnaire twice, while 350 completed the full panel. The analysis retained only children who had participated in the survey at least twice.

The data have been collected as part of a study on the Effects of Transnational Child Raising Arrangements on Life-chances of Children, Migrant Parents and Caregivers between Ghana and the Netherlands (TCRA Ghana), financed by the Dutch Research Council (NWO).

\section{Measures}

The study employs two self-reported measures of child education: school enjoyment and rank in class. For school enjoyment, children indicated on a scale from 1 to 5 how they generaly enjoy school, with higher scores reflecting beter outcomes. For rank in class, students were asked to indicate whether they are among best students in the class, rank in the middle, or 
most of the classmates rank better than they do. The self-reported measures of child education have been previously used and validated by research on transnational families (Cebotari \& Mazzucato, 2016; Cebotari et al., 2018; Cebotari et al., 2016; Jordan \& Graham, 2012). These studies show that self-reported measures of school enjoyment and school performance capture well variations in the education of children in transnational families and are more precise measurements compared to adult-reports of similar outcomes.

The analysis includes two variables of interest that relate to inernal and international parental migration and remittances. The first indicator details the type of parental migration and remittances: non migrant, parent(s) away internationally and sending monetary remittances, parent(s) away internationally and sending in-kind remittances, parent(s) away internationally and sending both monetary and in-kind remittances, parent(s) away internationally and sending no remittances, parent(s) away internally and sending monetary remittances, parent(s) away internally and sending in-kind remittances, parent(s) away internally and sending both monetary and in-kind remittances, parent(s) away internally and sending no remittances. The second indicator measures in a binary form whether monetary remittances are used for child's education.

The control variables include two individual-level characterisitcs: child's gender and age in full years. In addition, measurements include family characteristics in binary forms such as the education of the child's caregiver ( 1 = secondary education or more), the marital status of parents $(1=$ divorced $/$ separated $)$, and the stability of a child's care arrangement $(1=$ child changed caregiver one or more times since the parent has migrated). Another measure looks at 
the duration of child-parent separation: no separation, separation occurred in the past 12 months, and separation occurred over 13 months ago or more.

The study also employs two socioeconomic indicators of wealth. One indicator is an index of household assets that comprises information on assets such as the ownership of durable goods (house, refrigerator, computer, and means of ransportation) and the access to private utilities (toilet and bathing facilities). The second indicator is a binary measure of a child's general living conditions related to other children ( 1 = better living conditions).

Two additional measures account for the total number of children living with the child, and the number of younger children that live in the household. These indicators include both biological and non-biological siblings who currently live with the child.

Finally, a binary family process variable was included to measure the quality of the childcaregiver relationship, where 1 indicates a distant relationship (Cebotari et al., 2018; Jordan \& Graham, 2012). The child's main caregiver may be a parent, a family or a non-family member. Interaction terms were included to examine the moderating effects between gender and main variables of interest. The interactions were used to observe whether there are gender specific variations according to specifics of migration in the sample and over years.

\section{Analysis}

The analysis employs a fixed effects modelling strategy, which accounts for time-invariant characteristics and time events that may influence both child education and parental migration. The fixed effects approach allows estimating the effects of change in different forms of parental 
migration and remittances in relation to children's education over time. Considering the time varying component of fixed effects modelling, the measures employed in this study are those that change over time, except for gender of the child, which is retained in the analysis as part of the interaction terms.

The models included clusters of variables in a step-wise fashion to observe the progressive effects of indicators on child education outcomes. For brevity, only the full models are presented and discussed but the step-wise regressions are available upon request. Similarly, the full models only display interaction terms with significant coefficients. In the analysis, robust standard errors were estimated and corrected for clustering of observations at individual level. Indicators were tested for colliniarity and none was observed.

\section{RESULTS}

The descriptive overview of indicators employed in this study is presented in Table 1 . The average school enjoyment value in the sample and over years is 3.9 , on a scale from 1 to 5 . It reflects overall positive values of school enjoyment among the sampled population. Similarly, $40 \%$ of all children self-ranked themselves as being among the best students in the class. At the same time, $57 \%$ of children mentioned that they rank in the middle, with a small proportion of them reporting below average ranking (3.4\%).

Within the sampled population, $53 \%$ of children had at least one internal or international migrant parent over the years. A large majority of these parents sent monetary or in-kind remittances. Of those children whose parents sent remittances, the greatest proportion were receiving both monetary and in-kind remittances. Children with parents away internally or 
internationally who received only monetary remittances accounted for $4 \%$ and $3 \%$, respectively. A smaller proportion of children whose parents migrated internally or internationally received in-kind remittances only ( $2 \%$ and $1 \%$, respectively). Overall, more children with internal migrant parents did not received any remittances compared to children whose parents migrated abroad ( $13 \%$ and $3 \%$, respectively). In the sampled population of children, $28 \%$ received monetary remittances who were spent on education.

[Table 1 about here]

In the data, $48 \%$ of all respondents were female. The average age of children in the sample was $15.5(S D=1.98)$. Of all children, $44 \%$ had a caregiver who have completed secondary education or more. The proportion of children who have been separated from their migrant parents for less than a year accounted for $26 \%$. At the same time, $24 \%$ of children have been separated from their parents for a longer period. The stability of care indicator shows that $29 \%$ of children changed their caregiver once or more since parents have migrated. A similar proportion of children (30\%) had parents who were divorced or separated. In general, children report having good living conditions: approximately half of all children indicated having better living conditions compared to other children. Furthermore, the average value in the asset index was 3.7 $(\mathrm{SD}=1.51)$, on an asset scale from 1 to 6 . Furthermore, children reported living with up to three other children at home and indicated having, on average, $1.4(\mathrm{SD}=1.35)$ younger siblings in the residence. Finally, most children reported a good relationship with their caregiver at home.

To understand how the dynamics of migration and remittances unfold, it is important to observe the change in these dynamics over years. Table 2 presents the transition rates of 
internal and international parental migration as per types of remittances. Data on transition rates revealed changes in parental migration status as well as in the remitting behavior. In the observed period, $87 \%$ of children in nonmigrant families remained so. Of those children who transitioned from having a nonmigrant parent to a migrant parent $(23 \%)$, more children had parents who migrated internally than internationally. Similarly, when children transitioned from having a parent migrant to living with both parents, more did so who had a parent away internally than internationally.

[Table 2 about here]

Of all children with internal and international migrant parents who received only monetary remittances, $26 \%$ and $38 \%$, respectively, kept receiving so. When changes in the monetary remittances occurred, most transitions were made towards receiving both in-kind and monetary remittances, and to no remittances. Notable, transition rates from monetary remittances only to in-kind remittances only are insignificant or nonexistent for both internal and international parental migration.

Overall, the least preferred remitting channel over years is for international migrant parents to send only in-kind remittances: all these parents transitioned to sending either both in-kind and monetary remittances (75\%) or no remittances (25\%). The stronger remitting channel over years for both internal and international migrant parents is represented by the ability to send both in-kind and monetary remittances. From one year to another, $42 \%$ of internal migrants and $69 \%$ of international migrants who were sending both types of remittances kept sending so. At the same time, a relatively high proportion of internal and international migrant parents have not been sending any types of remittances over the years. Children whose internal and 
international migrant parents did not sent any remittances accounted for $57 \%$ and $29 \%$, respectively. These data illustrate that remittances and parental migration are dynamic processes. The time varying patterns of migration and remittances give a greater weight to the need to conduct a longitudinal analysis in the context of this study.

The results of transition rates revealed interesting patterns on how parental migration and the types of remittances unfold over time for children living transnationally. In the next stage of analysis, multivariate models are employed to observe the time varying effects of migration and remittances on education outcomes. Table 3 displays the full fixed effects models for parental migration and the types of remittances in relation to school enjoyment and class ranking.

When parental migration and types of remittances were considered (Table 3), children with parents away internationally and receiving both in-kind and monetary remittances were more likely to have higher levels of school enjoyment and class ranking as compared with children in nonmigrant families ( $\beta=0.50$ and $\beta=0.04$, respectively). Furthermore, results show that children were more likely to report a lower rank in class when parents were away internationally and did not sent remittances as compared to children living with both parents ( $\beta$ $=-0.04)$. In addition, children of internal migrant parents who received in-kind remittances only, or both types of remittances were more likely to have higher levels of school enjoyment ( $\beta=0.57$ and $\beta=0.53$, respectively) when compared to children in nonmigrant families. Net of other factors, the estimated coefficients for international migration (monetary remittances only, and in-kind remittances only), and for internal migration (monetary remittances only, and no remittances) were not statistically significant in relation to both educational outcomes. 
[Table 3 about here]

When measuring the migration and remittances effects, significant interaction terms were found between these characteristics and child gender. Specifically, interaction effects revealed that girls were less likely to report a higher class ranking when parents were away internally and were not sending remittances $(\beta$ of the interaction term $=-0.02$ ). Furthermore, being a girl reduced the overall positive effect on school enjoyment when there was an internal migrant parent who sent only in-kind remittances $(\beta$ of the interaction term $=-0.21$ ).

When controlling for the use of remittances, results show that a monetary investment in children's education is a likely predictor for a better class ranking. However, this effect was not replicated for school enjoyment. Furthermore, age was a significant predictor and shows that older children are more likely to report better levels of school enjoyment. A longer duration of separation, and especially one that lasted for more than a year, corresponded to a lower likelihood that children will report higher levels of school enjoyment and class ranking. The household asset index was a significant predictor for a higher class ranking but not for school enjoyment. Notable, a distant relationship with the caregiver shows a negative association with both educational outcomes.

Taken together, these results suggest that child education benefits when parents migrate internally or internationally and send a steady inflow of both in-kind and monetary remittances. Furthermore, child education additionally benefits when remittances are invested in child education and when children are older and live in wealthier households. At the same time, there are gender differences in children's education that are dependent on settings that include internal migration and volatile remitting channels. 


\section{DISCUSSION}

This study is the first to employ longitudinal evidence to comparatively assess the effects of internal and international parental migration and remittances in relation to child education in an African context. For the most part, existing studies rely on snapshot data to inform the evidence-base on African transnational families and child wellbeing. The panel evidence of this study allows for a higher accuracy when modelling the time-varying effects of migration and child education. The findings add two reflections to current knowledge on the effects of migration and child education. First, internal and international parental migration, and monetary and in-kind remittances are important differentiating factors as to whether child education benefits or suffers. Second, the gender of the child shows patterns of vulnerability when associated with parental migration, remittances, and education. These findings are discussed below.

This study includes measures of internal and international parental migration and different types of remittances to reflect more accurately the multifaceted nature of how children experience with living transnationally. Whether parents migrate internally or internationally and the type of remittances they send are important differentiating factors for child education. Specifically, children whose parents migrate internally or internationally and receive both monetary and in-kind remittances are more likely to have higher levels of school enjoyment and a better class ranking. When remittances are specifically invested in child education, they are likely to predict a better rank in class. At the same time, the absence of monetary and inkind remittances is likely to negatively affect the education of children, especially of girls. In Ghana and elsewhere, remittances are seen as vital resources to access quality education and 
to care for children through school (Cebotari, 2018; Kandel \& Kao, 2001; Poeze, 2018). Indeed, remittances are used to pay for a variety of school costs and this investment was found to have positive effects on children's educational outcomes (Antman, 2012; Cebotari et al., 2016;

Edwards \& Ureta, 2003). Furthermore, in Ghana, education is highly prized, and many parents invest in children's schooling as they expect higher returns later in a child's life (Poeze, 2018).

Findings of this study emphasize the preference of Ghanaian parents towards sending both inkind and monetary remittances when away internally or internationally. Over years, the remitting flow of many migrant parents converge towards sending both types of remittances. Monetary and in-kind remittances represent an exchange that creates a sense of care and connectivity between children and migrant parents (Coe, 2011). Migrant parents are likely to substitute the proximity of care with money and gifts, thus creating what is described by Parreñas (2001) as the 'commodification of love'. In addition to remittances, migrant parents engage with new media and communication technologies to foster intimate ties and help with childcare from afar (Baldassar, Nedelcu, Merla, \& Wilding, 2016; Poeze, 2018). Through these channels, migrant parents stay engaged in the family decision-making, including in decisions related to children's schooling (Cebotari \& Mazzucato, 2016; Poeze, 2018).

Importantly however, parental access to financial resources defines the way in which parents can meet children's material needs and invest in their education. Findings of this study show that of all children whose parents migrated internally and internationally, $57 \%$ and $29 \%$, respectively, did not receive any remittances over years. The absence of remittances may reflect negatively on children's education, especially on girls, as findings of this study show. The high proportion of parents who did not send remittances may reflect the volatile nature of 
work and the hardship that many Ghanaian parents face at the destination. When parents migrate, there are expectations of material benefits from children and families who stay behind (Poeze, 2018). The difficult situations that many parents encounter at the destination may lead to unmet expectations and unstable remitting flows, which may affect the wellbeing of children, including their educational outcomes.

The findings of this study also point to gender differences, in that internal migration is more likely to negatively affect girls' school enjoyment and class ranking when parents send no remittances or in-kind remittances only. These findings may echo the weak earning potential of internal migrants in Ghana compared to those away internationally (Ackah \& Medvedev, 2012; Mazzucato, Boom, \& Nsowah-Nuamah, 2008). Less remittances influence how investments are made in children, with girls more negatively affected (Cebotari et al., 2018; Lu, 2014). When remittances are scarce, Ghanaian girls are more likely to compensate for labor shortages in the household and they change caregivers more often compared to boys (Whitehead et al., 2007). To the extent that parental migration may exacerbate gender inequalities in transnational families, more research is needed on how migration, remittances and gender differences interlink in Ghana.

There are several limitations to this study. One limitation is the difficulty to model the internal and international migration and remittances as per which parent has migrated. Due to limited sample size, this distinction could not retain enough observations for a viable modelling. The migrant selectivity is an inherent limitation for studies that employ quantitative data. There are no empirical tools to holistically control for migrant selectivity over time, and the reader needs to be alert of this limitation. The data employed in this study comprise three rounds of 
observations. Therefore, data capture only short to medium effects of migration and remittances on child education. Data also include children who attend school and the results may not be generalizable to the entire population of Ghanaian children.

Despite these limitations, this study adds a longitudinal perspective on the effects of parental migration, remittances and child education in an African context. It does so by employing child reports to measure associations of interest. This is a novel contribution, in that existing evidence on children in transnational care is preponderantly based on assessments made by adults. To the extent that children's voices must feature more prominently in research on child wellbeing, this study concludes that parental migration is not necessarily a vulnerability for the education of children in Ghana. 
Table 1

Means/percentages (standard deviations) of dependent and independent variables

\begin{tabular}{lcc}
\hline & \multicolumn{2}{c}{ Full panel sample } \\
\cline { 2 - 3 } Variables & \% / mean (SD) & $\mathrm{N}$ \\
\hline School enjoyment & $3.94(0.95)$ & 1717 \\
Rank in class & 100 & 1717 \\
Most of classmates rank better than me & 3.44 & 59 \\
I rank in the middle & 56.61 & 972 \\
I am among the best students in class & 39.95 & 688 \\
Parental migration and remittances & 100 & 1717 \\
Both parents resident, non-migrant & 46.88 & 805 \\
Parent(s) away internationally: monetary remittances only & 2.74 & 47 \\
Parent(s) away internationally: in-kind remittances only & 0.64 & 11 \\
Parent(s) away internationally: monetary \& in-kind remittances & 16.25 & 279 \\
Parent(s) away internationally: no remittances & 3.03 & 52 \\
Parent(s) away internally: monetary remittances only & 4.25 & 73 \\
Parent(s) away internally: in-kind remittances only & 1.63 & 28 \\
Parent(s) away internally: monetary \& in-kind remittances & 11.24 & 193 \\
Parent(s) away internally: no remittances & 13.34 & 229 \\
Remittances used for child's education & 28.01 & 481 \\
Child is girl & 47.87 & 822 \\
Child age (years) & $15.58(1.98)$ & 1717 \\
Caregiver's education secondary or more & 44.44 & 763 \\
Duration of separation: none & 50.2 & 862 \\
Duration of separation: $\leq 12$ months & 25.63 & 440 \\
Duration of separation: 13 $\geq$ months & 24.17 & 415 \\
Parents divorced/separated & 29.94 & 514 \\
Child changed caregiver $\geq 1$ & 29.18 & 501 \\
Living conditions are better when compared to other children & 49.56 & 851 \\
Household asset index & $3.69(1.51)$ & 1717 \\
Total number of children living with the child & $2.97(2.08)$ & 1717 \\
Total number of younger children living with the child & $1.4(1.35)$ & 1717 \\
Distant relationship with the caregiver & 18.81 & 323 \\
\hline Notes: Standard deviations in parentheses. & &
\end{tabular}


Table 2

Transition rates for parental migration and remittances in the panel years (2013 to 2015)

\begin{tabular}{|c|c|c|c|c|c|c|c|c|c|c|c|}
\hline Parental migration and remittances & $\begin{array}{c}\text { Both } \\
\text { parents } \\
\text { resident, } \\
\text { non- } \\
\text { migrant }\end{array}$ & $\begin{array}{c}\text { Parent(s) } \\
\text { away } \\
\text { internatio } \\
\text { nally: } \\
\text { monetary } \\
\text { remittance } \\
\text { s only }\end{array}$ & $\begin{array}{c}\text { Parent(s) } \\
\text { away } \\
\text { internationa } \\
\text { 1ly: in-kind } \\
\text { remittances } \\
\text { only }\end{array}$ & $\begin{array}{c}\text { Parent(s) } \\
\text { away } \\
\text { internatio } \\
\text { nally: } \\
\text { monetary } \\
\text { \& in-kind } \\
\text { remittance } \\
\text { s }\end{array}$ & $\begin{array}{l}\text { Parent(s) } \\
\text { away } \\
\text { internationa } \\
\text { lly: no } \\
\text { remittances }\end{array}$ & $\begin{array}{c}\text { Parent(s) } \\
\text { away } \\
\text { internally: } \\
\text { monetary } \\
\text { remittances } \\
\text { only }\end{array}$ & $\begin{array}{c}\text { Parent(s) } \\
\text { away } \\
\text { internally: } \\
\text { in-kind } \\
\text { remittances } \\
\text { only }\end{array}$ & $\begin{array}{c}\text { Parent(s) } \\
\text { away } \\
\text { internall } \\
\text { y: } \\
\text { monetar } \\
\text { y \& in- } \\
\text { kind } \\
\text { remittan } \\
\text { ces } \\
\end{array}$ & $\begin{array}{l}\text { Parent(s) } \\
\text { away } \\
\text { internally } \\
: \text { no } \\
\text { remittanc } \\
\text { es }\end{array}$ & Total & $\mathrm{N}$ \\
\hline Both parents resident, non-migrant & 86.78 & 0.21 & 0 & 1.71 & 0.64 & 1.28 & 0.21 & 3.84 & 5.33 & 100 & 805 \\
\hline $\begin{array}{l}\text { Parent(s) away internationally: monetary } \\
\text { remittances only }\end{array}$ & 8.33 & 37.50 & 0 & 20.73 & 20.94 & 8.33 & 0 & 0 & 4.17 & 100 & 47 \\
\hline $\begin{array}{l}\text { Parent(s) away internationally: in-kind } \\
\text { remittances only }\end{array}$ & 0 & 0 & 0 & 75 & 25 & 0 & 0 & 0 & 0 & 100 & 11 \\
\hline $\begin{array}{l}\text { Parent(s) away internationally: monetary } \& \text { in- } \\
\text { kind remittances }\end{array}$ & 7.73 & 7.18 & 1.10 & 68.51 & 6.08 & 0 & 0.55 & 4.42 & 4.42 & 100 & 279 \\
\hline Parent(s) away internationally: no remittances & 12.90 & 12.90 & 12.90 & 22.58 & 29.03 & 0 & 0 & 3.23 & 6.45 & 100 & 52 \\
\hline $\begin{array}{l}\text { Parent(s) away internally: monetary } \\
\text { remittances only }\end{array}$ & 12.77 & 2.13 & 0 & 2.13 & 0 & 25.53 & 2.13 & 31.91 & 23.40 & 100 & 73 \\
\hline $\begin{array}{l}\text { Parent(s) away internally: in-kind remittances } \\
\text { only }\end{array}$ & 5.88 & 0 & 0 & 0 & 5.88 & 0 & 23.53 & 23.53 & 41.18 & 100 & 28 \\
\hline $\begin{array}{l}\text { Parent(s) away internally: monetary \& in-kind } \\
\text { remittances }\end{array}$ & 18.02 & 0 & 0.90 & 5.41 & 0.90 & 11.71 & 4.50 & 42.34 & 16.22 & 100 & 193 \\
\hline Parent(s) away internally: no remittances & 15 & 0.83 & 0 & 0 & 2.50 & 5.83 & 2.50 & 16.67 & 56.67 & 100 & 229 \\
\hline
\end{tabular}

Note: The changes in panel years are reflected in the rows 
Table 3

Internal and international parental migration, monetary and in-kind remittances, and educational outcomes - fully adjusted models

\begin{tabular}{|c|c|c|c|c|}
\hline & \multicolumn{2}{|c|}{$\begin{array}{c}\text { School enjoyment } \\
\text { Model } 1\end{array}$} & \multicolumn{2}{|c|}{$\begin{array}{l}\text { Rank in class } \\
\text { Model } 2\end{array}$} \\
\hline & $\beta$ & SE & $\beta$ & SE \\
\hline \multicolumn{5}{|l|}{ Parental migration status } \\
\hline \multicolumn{5}{|l|}{ Both parents resident, non-migrant } \\
\hline Parent(s) away internationally: monetary remittances only & 0.22 & $(0.24)$ & 0.18 & $(0.14)$ \\
\hline Parent(s) away internationally: in-kind remittances only & -0.09 & $(0.33)$ & -0.03 & $(0.19)$ \\
\hline Parent(s) away internationally: monetary \& in-kind remittances & $0.50 * *$ & $(0.22)$ & $0.04 *$ & $(0.03)$ \\
\hline Parent(s) away internationally: no remittances & -0.02 & $(0.19)$ & $-0.04 * *$ & $(0.10)$ \\
\hline Parent(s) away internally: monetary remittances only & 0.31 & $(0.23)$ & -0.03 & $(0.12)$ \\
\hline Parent(s) away internally: in-kind remittances only & $0.57 * *$ & $(0.22)$ & 0.08 & $(0.14)$ \\
\hline Parent(s) away internally: monetary $\&$ in-kind remittances & $0.53 *$ & $(0.21)$ & 0.08 & $(0.11)$ \\
\hline Parent(s) away internally: no remittances & 0.39 & $(0.16)$ & 0.12 & $(0.10)$ \\
\hline Remittances used for child's education & 0.02 & $(0.11)$ & $0.09 * *$ & $(0.04)$ \\
\hline Child is girl & 0.43 & $(0.30)$ & 0.03 & $(0.09)$ \\
\hline Child age (years) & $0.11 *$ & $(0.05)$ & 0.01 & $(0.02)$ \\
\hline Caregiver's education secondary or more & -0.04 & $(0.09)$ & 0.04 & $(0.04)$ \\
\hline Duration of separation: none & & & & 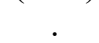 \\
\hline Duration of separation: $\leq 12$ months & $-0.46^{* *}$ & $(0.16)$ & -0.05 & $(0.09)$ \\
\hline Duration of separation: $13 \geq$ months & $-0.44 * *$ & $(0.16)$ & $-0.08 *$ & $(0.09)$ \\
\hline Parents divorced/separated & -0.07 & $(0.10)$ & -0.04 & $(0.06)$ \\
\hline Child changed caregiver $\geq 1$ & -0.02 & $(0.09)$ & 0.01 & $(0.04)$ \\
\hline Living conditions are better when compared to other children & 0.11 & $(0.07)$ & 0.05 & $(0.03)$ \\
\hline Household asset index & 0.01 & $(0.03)$ & $0.05 * *$ & $(0.01)$ \\
\hline Total number of children living with the child & 0.01 & $(0.02)$ & 0.02 & $(0.01)$ \\
\hline Total number of younger children living with the child & -0.00 & $(0.04)$ & -0.02 & $(0.02)$ \\
\hline Distant relationship with the caregiver & $-0.29 * * *$ & $(0.08)$ & $-0.01^{*}$ & $(0.04)$ \\
\hline Parent(s) away internally: in-kind remittances only $\mathrm{x}$ & $-0.21 *$ & $(0.13)$ & - & \\
\hline Female & & & & \\
\hline Parent(s) away internally: no remittances x Female & - & & $-0.02 *$ & $(0.01)$ \\
\hline Wave-fixed effects & Yes & & Yes & \\
\hline Child-fixed effects & Yes & & Yes & \\
\hline Unique number of children & 713 & & 713 & \\
\hline Total number of observations & 1717 & & 1717 & \\
\hline R-squared & 0.07 & & 0.05 & \\
\hline
\end{tabular}

Notes. Standard errors in parentheses (adjusted to account for clustering within individuals)

$* p<.05, * * p<.01, * * * p<.001$ 


\section{References}

Ackah, C., \& Medvedev, D. (2012). Internal migration in Ghana: determinants and welfare impacts. International Journal of Social Economics, 39(10), 764-784. doi:10.1108/03068291211253386

Acosta, P. (2011). School attendance, child labour, and remittances from international migration in El Salvador. The Journal of Development Studies, 47(6), 913-936. doi:10.1080/00220388.2011.563298

Adams, R. H., \& Page, J. (2005). Do international migration and remittances reduce poverty in developing countries? World Development, 33(10), 1645-1669. doi:10.1016/j.worlddev.2005.05.004

Antman, F. M. (2012). Gender, educational attainment and the impact of parental migration on children left behind. Journal of Population Economics, 25(4), 1187-1214. doi:10.1007\%2Fs00148-0120423-y

Baldassar, L., Nedelcu, M., Merla, L., \& Wilding, R. (2016). ICT-based co-presence in transnational families and communities: challenging the premise of face-to-face proximity in sustaining relationships. Global Networks, 16(2), 133-144. doi:10.1111/glob.12108

Bledsoe, C., \& Sow, P. (2011). Back to Africa: Second Chances for the Children of West African immigrants. Journal of Marriage and Family, 73, 747-762. doi:10.1111/j.17413737.2011.00843.x

Bowlby, J. (1958). The Nature of the Child's Tie to the Mother. International Journal of Psycho-Analysis, 39(5), 350-373.

Bredl, S. (2010). Migration, remittances and educational outcomes: the case of Haiti. International Journal of Educational Development,, 31(2), 162-168. doi:10.1016/j.ijedudev.2010.02.003

Brown, R., \& Poirine, B. (2005). A model of migrants' remittances with human capital investment and intrafamilial transfers. International Migration Review, 39(2), 407-438. doi:10.1111/j.17477379.2005.tb00272.x

Cebotari, V. (2018). Transnational migration, gender and educational development of children in Tajikistan. Global Networks, 18(4), 564-588. doi:10.1111/glob.12193

Cebotari, V., \& Mazzucato, V. (2016). Educational performance of children of migrant parents in Ghana, Nigeria and Angola. Journal of Ethnic and Migration Studies, 42(5), 834-856 doi:10.1080/1369183X.2015.1125777

Cebotari, V., Mazzucato, V., \& Appiah, E. (2018). A longitudinal analysis of well-being of Ghanaian children in transnational families. Child Development, 89(5), 1168-1785. doi:10.1111/cdev.12879

Cebotari, V., Siegel, M., \& Mazzucato, V. (2016). Migration and the education of children who stay behind in Moldova and Georgia. International Journal of Educational Development, 51(November), 96-107. doi:10.1016/j.ijedudev.2016.09.002

Coe, C. (2011). What is love? The materiality of care in Ghanaian transnational families. International Migration, 49(6), 7-24. doi:10.1111/j.1468-2435.2011.00704.x

Cortes, P. (2015). The feminization of international migration and its effects on the children left behind: Evidence from the Philippines. World Development, 65(January), 62-78. doi:10.1016/j.worlddev.2013.10.021

Edwards, A., \& Ureta, M. (2003). International migration, remittances, and schooling: Evidence from El Salvador Journal of Development Economics, 72(2), 429-461. doi:10.1016/S03043878(03)00115-9

Gatskova, K., Ivlevs, A., \& Dietz, B. (2017). Does migration affect education of girls and young women in Tajikistan? . WIDER Working Paper 2017/104, 47. Retrieved from https://www.wider.unu.edu/sites/default/files/wp2017-104.pdf 
Ghana Statistical Service-Ghana Health Service and ICF International. (2014). Ghana Demographic and Health Survey 2014. Retrieved from: http://www.dhsprogram.com/

Government of Ghana. (2016). National migration policy for Ghana. Retrieved from Accra: http://migratingoutofpoverty.dfid.gov.uk/files/file.php?name=national-migration-policy-forghana.pdf\&site=354

Hu, F. (2012). Migration, remittances, and children's high school attendance: The case of rural China. International Journal of Educational Development, 32(2), 401-411. doi:10.1016/j.ijedudev.2011.08.001

Jampaklay, A. (2006). Parental absence and children's school enrolment. Evidence from a longitudinal study in Kanchanaburi, Thailand. Asian Population Studies, 2(1), 93-110. doi:10.1080/17441730600700598

Jordan, L. P., \& Graham, E. (2012). Resilience and well-being among children of migrant parents in South-East Asia. Child Development, 83(5), 1672-1688. doi:10.1111/j.1467-8624.2012.01810.x

Kandel, W., \& Kao, G. (2001). The impact of temporary labor migration on Mexican children's educational aspirations and performance. International Migration Review, 35(4), 1205-1231. doi: $10.1111 /$ j.1747-7379.2001.tb00058.x

Kroeger, A., \& Anderson, K. H. (2014). Remittances and the human capital of children: New evidence from Kyrgyzstan during revolution and financial crisis, 2005-2009. Journal of Comparative Economics, 42(3), 770-785. doi:10.1016/j.jce.2013.06.001

Lu, Y. (2014). Parental migration and education of left-behind children: A comparison of two settings. Journal of Marriage and Family, 76(5), 1082-1098. doi:10.1111/jomf.12139

Mazzucato, V., Boom, B. v. d., \& Nsowah-Nuamah, N. N. N. (2008). Remittances in Ghana: Origin, destination and issues of measurement. International Migration Review, 46(1), 103-122. doi:10.1111/j.1468-2435.2008.00438.x

Mazzucato, V., \& Cebotari, V. (2016). Psychological well-being of Ghanaian children in transnational families. Population Space and Place. doi:10.1002/psp.2004

Molini, V., \& Paci, P. (2015). Poverty Reduction in Ghana : Progress and Challenges. Retrieved from Washington, DC: https://openknowledge.worldbank.org/handle/10986/22732

Molini, V., Pavelesku, D., \& Ranzani, M. (2016). Should I Stay or Should I Go? Internal Migration and Household Welfare in Ghana. Policy Research Working Paper. Retrieved from http://elibrary.worldbank.org/doi/abs/10.1596/1813-9450-7752 doi:10.1596/1813-9450-7752

Morooka, H., \& Liang, Z. (2009). International Migration and the Education of Left Behind Children in China Asian and Pacific Migration Journal, 18(3), 345-370.

Nobles, J. (2011). Parenting from abroad: migration, nonresident father involvement, and children's education in Mexico. Journal of Marriage and Family, 73(4), 729-746. doi:10.1111/j.17413737.2011.00842.x

Parreñas, R. (2001). Mothering from a distance: Emotions, gender, and inter-generational relationships in Filipino transnational families. Feminist Studies, 27(2), 361-390. doi:10.2307/3178765

Parreñas, R. (2005). Children of global migration: Transnational families and gendered woes. Stanford, CA: Stanford University Press.

Poeze, M. (2018). Migration, family separation and caregiving across borders: A multi-sited ethnography of transnational child-raising arrangements between Ghana and The Netherlands. (PhD), Maastricht University, Maastricht Retrieved from https://cris.maastrichtuniversity.nl/portal/files/31350116/c6222 embargo chapter5en7.pdf

Rapoport, H., \& Docquier, F. (2006). The economics of migrants' remittances. In S.-C. Kolm \& J. M. Ythier (Eds.), Handbook of the Economics of Giving, Alturism, and Reciprocity (Vol. 2, pp. 1135-1198). Amsterdam: Elsevier. 
Stark, O., \& Bloom, D. E. (1985). The new economics of labour migration. American Economic Review, 75(2), 174-178.

Thomson, E., Hanson, T. L., \& McLanahan, S. S. (1994). Family structure and child well-being: Economic resources vs. parental behaviors. Social Forces, 1, 221-242. doi:10.2307/2579924

United Nations. Department of Economic and Social Affairs. Population Division. (2017). Trends in International Migrant Stock: The 2017 revision. Retrieved from:

https://www.un.org/en/development/desa/population/migration/data/estimates2/estimates17 .asp

Wen, M., \& Lin, D. (2012). Child development in rural China: Children left behind by their migrant parents and children of nonmigrant families. Child Development, 83(1), 120-136. doi:10.1111/j.1467-8624.2011.01698.x

Whitehead, A., Hashim, I. M., \& Iversen, V. (2007). Child migration, child agency and intergenerational relations in Africa and South Asia. Development Research Centre on Migration, Globalisation and Poverty. Brighton. Retrieved from http://r4d.dfid.gov.uk/PDF/Outputs/MigrationGlobPov/WP-T24.pdf

World Bank. (2018). Migration and remittances. Recent developments and outlook. Retrieved from https://www.knomad.org/sites/default/files/201812/Migration\%20and\%20Development\%20Brief\%2030.pdf

Wu, Q., \& Cebotari, V. (2018). Experiences of migration, parent-child interaction, and the life satisfaction of children in Ghana and China. Population Space and Place, 24(7), e2160. doi:10.1002/psp.2160 